Diabetologia 5, 260-262 (1969)

\title{
Glucose Stimulation of Insulin Secretion from the Isolated Pancreas of Foetal and Newborn Rats*
}

\author{
K. Asplund, S. Whistman and C. Hellerström \\ Histological Department, University of Uppsala, Uppsala, Sweden \\ Received: November 18, 1968
}

Summary. Pancreatic glands of 22-day-old rat foetuses or $0-12$ day old rats were incubated in a KrebsRinger phosphate-buffered salt solution, and the insulin secrotion measured at a lower $(0.6 \mathrm{mg} / \mathrm{ml})$ or a higher ( $3 \mathrm{mg} / \mathrm{ml}$ ) glucose concentration in the medium. Stimulation of the insulin release by glucose could not be detected until the second postnatal day, when there was a marked increase in the amount of hormone secreted into the medium. Since the presence of insulin has been demonstrated in the B-cells of rat foetuses, the data suggest that in this species the cellular mechanism for insulin synthesis becomes manifest considerably earlier than that for glucose-regulated insulin release.

Stimulation par le glucose de la sécrétion d'insuline par le pancréas isolé de rats foetaux et nouveau-nés

Résumé. Les glandes pancréatiques de foetus de rats âgés de 22 jours ou de rats âgés de $0-12$ jours ont été incubées dans une solution tampon au phosphate de Krebs Ringer, et la sécrétion d'insuline a été mesurée pour une faible concentration de glucose $(0.6 \mathrm{mg} / \mathrm{ml})$ ou pour une concentration de glucose plus élevée $(3 \mathrm{mg} / \mathrm{ml})$ dans le milieu. La stimulation de la libération d'insuline par le glucose ne pouvait pas être décelée jusqu'au deuxième jour postnatal, où il y avait une nette augmentation de la quantité d'hormone sécrétée dans le milieu.
Puisque la présence d'insuline a été démontrée dans les cellules $\mathbf{B}$ de foetus de rats, les données suggèrent que dans cette espèce le mécanisme cellulaire de la synthèse de l'insuline devient manifeste beaucoup plus tôt que celui de la libération d'insuline régulée par le glucose.

Stimulation der Insulinsekretion mit Glucose aus dem isolierten Pankreas von foetalen und neugeborenen Ratten

Zusammenfassung. Das Pankreas von 22 Tage alten Rattenfoeten oder $0-12$ Tage alten Ratten wurde in einer Krebs-Ringer-Phosphat-Puffer-Lösung inkubiert, und die Insulin-Sekretion bei einer niedrigeren $(0.6 \mathrm{mg} / \mathrm{ml})$ oder höheren $(3 \mathrm{mg} / \mathrm{ml})$ Glucosekonzentration der Lösung gemessen. Stimulation der Insulinfreisetzung durch Glucose konnte bis zum 2. postnatalen Tag nicht festgestellt werden, an dem ein bemerkenswerter Anstieg des in die Lösung sezernierten Hormons eintrat. Da die Gegenwart von Insulin in den B-Zellen von Rattenfoeten gezeigt wurde, lassen die Werte vermuten, daß sich bei dieser Spezies der Zellmechanismus für Insulin-Synthese beträchtlich früher manifestiert als die glucoseregulierte Insulinfreisetzung.

Key-words: Insulin secretion, isolated pancreas, pancreas of foetal rats.

\section{Introduction}

There is much evidence to indicate that synthesis of insulin occurs in the pancreatic B-cells at a rather early stage of mammalian foetal development. Morphological studies in man have demonstrated storage of the hormone as cytoplasmic secretion granules already at a foetal age of about $10-12$ weeks $[2,3,12]$, and insulin is present in the B-cells in foetuses of the rat, guinea-pig, sheep and mouse before the last third of the gestational period $[1,8,10,17,19,20]$. The correlation between the morphological maturation of the B-cell and the development of the mechanisms for regulation of insulin release is, however, poorly understood. An approach to this question has been made in the present study by measuring the insulin release from foetal and neonatal rat pancreas incubated in media with different glucose concentrations.

\section{Materials and Methods}

Foetal and neonatal Sprague-Dawley rats of both sexes were used. The foetal age was estimated with

* This investigation was supported by grants from the Medical Faculty of Uppsala, the Swedish Medical Research Council (B69-12X-109-05A) and the U.S. Public Health Service (AM-12535). an accuracy of $\pm 5 \mathrm{~h}$, and the post-partum age was determined on the basis of witnessed delivery. The neonatal rats remained with their mothers until the start of the experiment.

After decapitation of the animal the pancreas was quickly excised, rinsed in incubation medium, blotted on filter paper, weighed and suspended in ice-cold medium. The subsequent incubations were performed mainly as described by CoORE and RANDLE [4]. The incubation medium consisted of Krebs-Ringer phosphate-buffered salt solution [21] supplemented with bovine serum albumin, $2 \mathrm{mg} / \mathrm{ml}$ (Fraction V; Armour Pharmaceutical Co. Ltd., Eastbourne, England), together with pyruvate, glutamate and fumarate each at a concentration of $5 \mathrm{mM}$ [4]. Glucose was added to the medium at a concentration of 0.6 or $3.0 \mathrm{mg} / \mathrm{ml}$.

The pancreatic glands (10-20 mg wet weight) were incubated without slicing at $+37^{\circ} \mathrm{C}$ in Warburg vessels with constant shaking. The gas phase consisted of pure oxygen. After preincubation for half an hour at the lower glucose concentration, the glands were rinsed in fresh medium and incubated for a further $30 \mathrm{~min}$ in new vessels containing $0.5 \mathrm{ml}$ of medium with the same glucose concentration. This was followed by a final incubation period of the same length at the higher glucose concentration. Samples of the media from the 
two last incubation periods were immediately frozen for subsequent insulin determinations according to HaLes and RandLe [11]. Crystalline mouse insulin (approx. $23 \mathrm{IU} / \mathrm{mg}$ ) was used as a standard. Antibody and ${ }^{125}$ I-insulin were obtained from The Radiochemical Centre, Amersham, England. Duplicate assays were carried ont, the error of a single determination being $\pm 12 \%$. Absolute rates of insulin release have been expressed as $\mathrm{ng} / \mathrm{mg}$ wet weight per $30 \mathrm{~min}$.

\section{Results}

As shown in Table 1 the rate of insulin release at the lower glucose concentration displayed small vari-

Table 1. Mean insulin secretion ( $\div$ S.E.M.) from incubated pancreatic glands of foetal and newborn rats. The significance of the difference between the secretion rates at lower and higher glucose concentrations in the incubation media is also shown

\begin{tabular}{|c|c|c|c|c|}
\hline $\begin{array}{l}\text { Age } \\
\text { Days }\end{array}$ & $\begin{array}{l}\text { Number of } \\
\text { observations } \\
\text { (Number of } \\
\text { litters) }\end{array}$ & $\begin{array}{l}\text { Insulin secr } \\
\text { (ng/mg pand } \\
0.6 \mathrm{mg} \\
\text { glucose } / \mathrm{ml}\end{array}$ & $\begin{array}{l}\text { etion } \\
\text { reas } / 30 \mathrm{~min} \text { ) } \\
\mathbf{3 . 0} \mathrm{mg} \\
\text { glucose } / \mathrm{ml}\end{array}$ & $P$ \\
\hline $\begin{array}{r}-1 / 2 \\
1 / 2 \\
1 \\
2 \\
3 \\
3 \\
5 \\
6 \\
12\end{array}$ & $\begin{aligned} 7 & (3) \\
8 & (3) \\
6 & (3) \\
11 & (2) \\
11 & (2) \\
6 & (2) \\
9 & (3) \\
7 & (1)\end{aligned}$ & $\begin{array}{l}1.5 \pm 0.3 \\
1.5 \pm 0.3 \\
1.8 \pm 0.7 \\
1.4 \pm 0.3 \\
1.7 \pm 0.2 \\
1.4 \pm 0.3 \\
1.7 \pm 0.3 \\
1.1 \pm 0.3\end{array}$ & $\begin{array}{l}1.5 \pm 0.3 \\
1.1 \pm 0.3 \\
0.7 \pm 0.2 \\
3.8 \pm 0.8 \\
5.6 \pm 0.9 \\
3.9 \pm 0.3 \\
4.1 \pm 0.9 \\
3.0 \pm 0.3\end{array}$ & $\begin{array}{l}>0.05 \\
>0.05 \\
>0.05 \\
<0.05 \\
<0.001 \\
<0.01 \\
<0.05 \\
<0.001\end{array}$ \\
\hline
\end{tabular}

ations between animals of different postnatal ages. This basal rate of insulin secretion was also of the same order as that observed just before birth. A stimulation of the insulin release by glucose could not be detected until the second postnatal day, when in most experiments there was a very marked increase in the amount of hormone secreted into the medium. It is worthy of note, however, that also on the second postnatal day 4 out of 11 glands remained unaffected by glucose. In the older animals only occasional specimens showed this lack of response. The great majority of pancreatic glands at these ages contained B-cells displaying a 2to 6 -fold increase of the insulin release during incubation with the higher glucose concentration.

\section{Discussion}

The present data indicate that stimulation in vitro of insulin release from the rat pancreas by glucose does not occur until the second postnatal day. Previous studies with morphological, histochemical and biochemical methods have conclusively demonstrated the presence of insulin in the B-cells of rats at about the 18 th intrauterine day $[5,6,8,18,20]$. It seems probable, therefore, that the cellular mechanism for insulin synthesis becomes manifest considerably earlier than that for glucose regulation of insulin release. There is, however, some evidence to suggest that the insulin storage of the B-cells is considerably raised by glucose administration to one-day-old rats [15]. Glucose might therefore enhance the synthesis of insulin before it becomes able to stimulate the release of this hormone.

The rate of morphological maturation of mammalian B-cells differs a great deal between various species. Whereas distinct secretion granules can be seen in the light microscope in man very early during the foetal life $[2,3,12]$, they have not been detected until the second half of gestation in the rat. It seems probable that corresponding differences exist in the development of the mechanism for the regulation of insulin release. In fact, recent data have shown that in the human newborn, glucose administration through the umbilical cord increased the blood level of immunoreactive insulin already a few hours after birth [13]. This increase was, however, much slower than that reported to occur upon intravenous administration of glucose in adult life and also in newborns of diabetic mothers [13]. The latter observation suggests that maternal diabetes may accelerate the functional maturation of the foetal B-cell.

Since insulin has been found not to penetrate the placental membranes of rats $[2 \mathrm{a}, 7]$, the possible demands for this hormone must be met by the foetal endocrine pancreas itself. It is, however, still obscure to what extent the foetus depends on a supply of insulin for its normal development. Insulin sensitivity (in terms of a facilitated glucose entry across cellular membranes) seems to develop gradually during intrauterine life [9]. Further studies are required to evaluate, to what extent insulin is present in the foetal blood circulation before the B-cell can respond to glucose, and what mechanisms are responsible for its secretion. In recent studies VECCHIO et al. [22] and LAMMBERT et al. [14] have shown that insulin secretion from the cultured foetal pancreas of rats may be stimulated by a number of factors other than glucose. In addition, MruNer and Wrighr [16] reported a prompt rise in the plasma insulin level after administration of glucagon in one-day-old human infants.

\section{References}

1. AtmXander, D.P., H.G. Britron, N.M. Cohen, D.A. Nixos, and R.A. PARKER: Insulin concentration in the foetal plasma and foetal fluids of the sheep. J. Endocr. 40, 389-390 (1968).

2. Björkmax, N., C. Helimiström, B. Hellman, and B. Perersson: The cell types in the endocrine pancreas of the human fetus. Z. Zellforsch. 72, 425-445 (1966).

2a. Clatk, C. M., G. F. Cantri, and J. S. Soemdner: Effects of exogenous insulin on the rate of fatty acid synthesis and glucose C-14 utilization in the twentyday rat fetus. Diabetes 17, 362-368 (1968).

3. CoNkLJN, J.L.: Cytogenesis of the human fetal pancreas. Amer. J. Anat. 111, 181-193 (1962).

4. COORE, H.G., and P.J. RandLE: Regulation of insulin secretion studied with pieces of rabbit pancreas incubated in vitro. Biochem. J. 93, 66-78 (1964). 
5. Dixit, P.K., I.P. Lowe, C.B. HegGestad, and A. LAzARow: Insulin content of microdissected fetal is lets obtained from diabetic and normal rats. Diabetes 13, 71-82 (1964).

6. FRye, B.E.: The differentiation of the endocrine pancreas in fetuses of alloxan diabetic and insulintreated rats. J. Morph. 101, 325-357 (1957).

7. Goodner, C.J., and N. Fretnker: Carbohydrate metabolism in pregnancy. IV. Studies on the permeability of the rat placenta to $I^{131}$ insulin. Diabetes 10, 383-392 (1961).

8. GRILLo, T.A.I.: The occurrence of insulin in the pancreas of foetuses of some rodents. J. Endocr. 31, $67-73(1964-65)$.

9. - G. Okuno, G. Gutdott, S. Price, and P.P. Foג: Studies on the ontogenesis of the pancreas. In: BroLIN, S.E., B. HELLMAN, and H. KNutson (eds.): The Structure and Metabolism of the Pancreatic Islets, pp. 157-171. London: Pergamon Press 1964.

10. Grossner, D. : Die Entwicklung der Langerhansschen Inseln und die Blutinseln beim Schaf. Z. mikr.-anat. Forsch. 76, 277-299 (1967).

11. Haliss, C.N., and P.J. RANDLE: Immunoassay of insulin with antibody precipitate. Biochem. J. 88, 137 $146(1963)$

12. JrRáseK, J.E.: Die Histogenese und Histochemie der Beta-Zellen der Langerhansschen Inseln im Pankreas menschlicher Embryonen. Acta histochem. (Jena) 22 , $62-65(1965)$.

13. Jørgensex, K.R., T. Dedkert, L.M. Pedersen, and J. Pmotersen: Insulin, insulin antibody and glucose in plasma of newborn infants of diabetic women. Acta endocr. (Kbh.) 52, 154-167 (1966).

14. Lambert, A. E., B. Jeanrenaud, and A. E. Renold: Enhancement by caffeine of glucagon-induced and tolbutamide-induced insulin release from isolated foetal pancreatic tissue. Lancet I, 819-820 (1967).
15. - A.F. Junod, L. Ord, B. Jganrenaud, A.E. ReNOLD, and Ch. RoutleER: Biological and morphological studies on foetal and newborn rat pancreas. Abstracts from the 4th annual meeting of the European Association for the study of Diabetes, Louvain, $p$. $69-70(1968)$

16. MrtNer, R.D.G., and A.D. WRIGHT: Plasma glucose, non-esterified fatty acid, insulin and growth hormone response to glucagon in the newborn. Clin. Sci. 32, $249-255$ (1967).

17. MUNGer, B.L.: A light and electron microscopic study of cellular differentiation in the pancreatic islets of the mouse. Amer. J. Anat. 103, 275-312 (1958).

18. Murrele, L.R., C.R. Morgan, and A. Lazarow: Mammalian pancreatic tissue in organ culture. II. Insulin contents of tissues and culture medium. Exp. Cell Res. 41, 365-375 (1966).

19. Petersson, B.: The two types of alpha cells during the development of the guinea-pig pancreas. Z. Zellforsch. 75, 371-380 (1966).

20. Schweisthat, M.R., L.J. Weles, and M.P. Ćías: Development of islets and acini from the explanted primordium of the pancreas of the rat embryo. Anat. Rec. 151, 93-105 (1965).

21. UMbreit, W.W., R.H. BuRRIS, and J.F. StaufFer : Manometric Techniques, ed. 4, p. 132. Minneapolis: Burgess Publishing Co. 1964.

22. Vecchro, D., A. LuyckX et A. E. Renold : Culture d'organe de pancréas foetal de rat: II. Effects du glucose, d'un sulfamidé hypoglycémiant et du glucagon sur la liberation de l'insuline. Helv. physiol. pharmacol. Acta 25, 134-146 (1967).

Dr. KJelu Aspuund Histological Department V. Ågatan $26 \mathrm{~A}$ 75220 Uppsala 1 (Sweden) 